\title{
Experimental Investigation into Pull-Out Strength of Foamed Concrete Using Different Types of Screw
}

\author{
M.A. Othuman Mydin ${ }^{1}$, N. Noordin ${ }^{2}$, Z.Matori ${ }^{3}$, N. Md Sani ${ }^{4}$, N.F. Zahari ${ }^{5}$ \\ ${ }^{1,2,3,4}$ School of Housing, Building and Planning, Universiti Sains Malaysia, 11800, Penang, Malaysia \\ ${ }^{5}$ Faculty of Architecture, Planning and Surveying, UiTM Perak, Seri Iskandar Campus, 32610, \\ Seri Iskandar, Perak, MALAYSIA
}

\begin{abstract}
This study focuses on the results of the comprehensive strength test to quantify the mechanical properties of the screw's pullout strength on foamed concrete. Foamed concrete is classified as lightweight concrete that been produced by cement paste or mortar in which air-voids are entrapped in the mortar by a suitable foaming agent. These days, the use of foamed concrete has been recognized in the construction industry as wall blocks, wall panels and also material floor and roof screeds. Hence, the applications of this material should be maximized as it is multi-functional. As we know, the use of screws on the wall or ceiling is common in a building. The objective of this research is to examine and determine the pullout strength of various properties and types of screws in lightweight foamed concrete with various densities that may depict the best result of the pullout strength on foamed concrete. To visualize the different results of pullout strength, screws with and without wall plug will be used as well. The pullout strength will be tested using the Universal Testing Machine where it shall measure the ultimate load of the screws attached to the foamed concrete may resist.
\end{abstract}

\section{Introduction}

Lightweight concretes are widely used in developed countries such as Germany, United Kingdom, Australia, United States, and Europe [1]. The main characteristic of this product is low in density with wide range of dry densities, typically from 400 to $1600 \mathrm{~kg} / \mathrm{m}^{3}$ which in addition, has lower tender mechanical properties compared to normal concrete strength $[2,3]$. It is a free flowing material which is ideal for an extensive range of applications [4]. Foamed concrete can easily be placed by means of pumping (if necessary) or manually by hand and easy to place in inaccessible places [5]. It does not require any compaction, vibrating or levelling. It has an excellent water and frost resistance component and provides high level of sound and thermal insulation [6,7].

Lightweight foamed concrete has been used in the construction industry for over 50 years since the introduction of cellular concrete system[8]. The use of foamed concrete has been almost exclusively limited to non-structural void filling, bridge abutment work, roof insulation, thermal insulation, acoustic damping, and trench filling for reinstatement of road and for building blocks $[9,10]$. The first usage of foamed concrete was recorded in early 1920 s and primarily employed as insulation material. 
The usage of lightweight foamed concrete is now rising in this country. It is used in low-rise residential construction as partition or load bearing the towering walls [11] In line with government requirements to encourage the use of IBS system, lightweight foamed concrete can enhance the transformation and strategy towards achieving this goal [12]. Some researches need to be executed in order to diversify the use of this concrete. Nowadays the use of foamed concrete has been utilized in the construction industry as wall blocks, wall panels and also floor \& roof screeds. Due to this situation, the application of this product must consider in many areas so that the usage can be maximized [13].

Pullout strength of screw on foamed concrete is a new idea in order to distinguish the performance of foamed concrete to be used in construction industry. This is following to the usage of screws as finishing and for the installation of furniture and electrical component [14].

To date, there is no single research conducted on this subject matter.. There is only published work to characterize the pullout failure in conical and cylindrical pedicle screws after full insertion and back-out. Pullout strength and load failure were measured by using a servo-hydraulic materials testing machine [15]. An adapter was made to fit securely around the head of screw. The adapter was attached to the load cell of the testing device.

As the ram of the testing machine moved, the adaptor allowed axial pull-out along the axis of the screw at a displacement rate of $25 \mathrm{~mm} / \mathrm{min}$. The MTS device and adaptor were re-evaluated before each test in order to ensure the specimen was fitted flush into the testing jig and the adaptor created an axial displacement preventing any off-axis loading of the screw [16,17]. A curve of pullout force (N) versus time was plotted for each specimen. Hence, a study needs to be done in order to determine the maximum suspended load by screw that can be applied on the foamed concrete. In order to determine the maximum suspended load, appropriate variables to be used must be planned wisely.

\section{Experimental Setup}

The foamed concrete used in this study was made from Ordinary Portland Cement (OPC), fine sand, water and stable foam. The concrete specimens were prepared with two different densities, 900 and $1250 \mathrm{~kg} / \mathrm{m}^{3}$. The density $900 \mathrm{~kg} / \mathrm{m}^{3}$ was selected because it may be used in lightweight partition and $1250 \mathrm{~kg} / \mathrm{m}^{3}$ density would have a useful amount of mechanical properties to make it competent as a light load bearing infill material, which may be combined with profiled thin walled steel in lightweight composite panel construction. Mix cement ratio for the sample with density $900 \mathrm{~kg} / \mathrm{m}^{3}$ is $1: 1.5: 0.45$. For density $1250 \mathrm{~kg} / \mathrm{m}^{3}$ the mix cement ratio is $1: 2.5: 0.45$. Foam is added after some calculations were made. Further details of the mix constituent proportions of both densities are outlined in Table 1. The targeted foamed concrete volume required for the mix design was $0.15 \mathrm{~m}^{3}$.

Table 1: Mix constituent proportions of foamed concrete mixes

\begin{tabular}{|c|c|c|c|}
\hline $\begin{array}{c}\text { Target dry density } \\
\left(\mathrm{kg} / \mathrm{m}^{3}\right)\end{array}$ & $\begin{array}{c}\text { Portland Cement content } \\
\left(\mathrm{kg} / \mathrm{m}^{3}\right)\end{array}$ & Sand content $\left(\mathrm{kg} / \mathrm{m}^{3}\right)$ & $\begin{array}{c}\text { Noraite PA-1 surfactant } \\
\left(\mathrm{m}^{3}\right)\end{array}$ \\
\hline 900 & 17.07 & 25.61 & 0.027 \\
\hline 1250 & 51.88 & 129.69 & 0.051 \\
\hline
\end{tabular}

\subsection{Sample Preparation}

Each density will use the same method of mixing. Stable foam was produced using foam generator Portafoam TM2 System, obtained from the Malaysian Manufacturer (www.portafoam.com). Noraite PA-1 (protein based) was used as foaming agent which is suitable for foamed concrete densities ranging from $400 \mathrm{~kg} / \mathrm{m}^{3}$ to $1600 \mathrm{~kg} / \mathrm{m}^{3}$. Noraite PA-1 comes from natural sources and weigh of around $80 \mathrm{~g} / 1$ and expands about 12.5 times when used with the portafoam foam generator. The samples used in this study were wall block and concrete cube. 


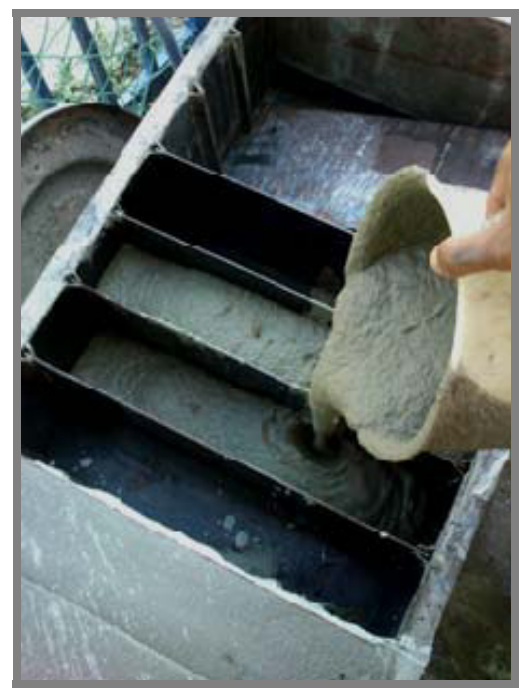

Figure 1. Placement of foamed concrete mix into the steel mould

Concrete was used to check compression strength of concrete while concrete block to be tested with screws to get the pullout strength of screw on foamed concrete. The size of wall block used is dimensioned $100 \times 200 \times 500 \mathrm{~mm}$ and for the cube is $100 \times 100 \times 100 \mathrm{~mm}$. Every mix will have 6 sample of concrete cube and 3 samples of wall block. Since this concrete is a foamed concrete and the workability is high, it didn't need compaction or vibration during the pouring process into the mould.. The sample will be removed from the mould after 24 hours. Fig. 1 shows the placement of foamed concrete mix into the steel mould.

\subsection{Types of screw}

There are 3 types of screws will be used in this test; (a) chipboard screw, (b) self-tapping screw, and (c) drywall screw as shown in Fig. 2. The screws that been used for this study have similar length of $50.8 \mathrm{~mm}$. Table 2 shows the detail of the screws.

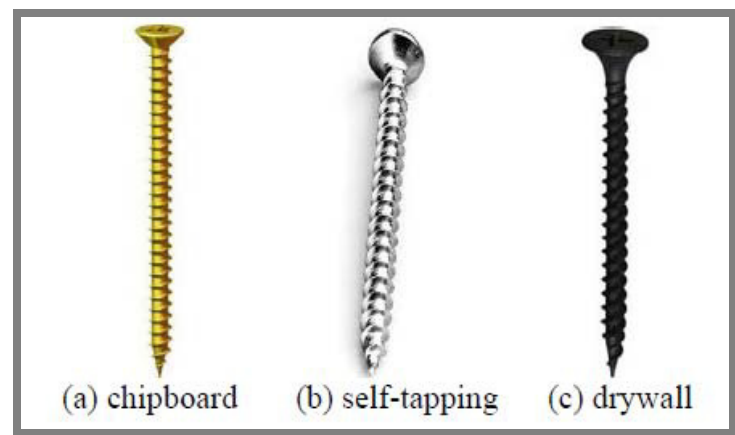

Figure 2: Types of screw used for this study

\subsubsection{Chipboard Screw / Particle Board Screw}

Chipboard screw is similar to drywall screw but it has a thinner shaft and provides better resistance to pullout in particle board, while offset against lower shear strength. The threads on particle board screws are asymmetrical. 


\subsubsection{Concrete Screw / Masonry Screw / Self-Tapping Screw}

Self-tapping screw is a stainless steel screw for fastening wood, metal or other materials into concrete or masonry. This type of screw may either have a Philips flat head or a slotted hex washer head. Usually the head of this screw is in the range of 0.1875 to $0.375 \mathrm{in}$. (4.763 to $9.525 \mathrm{~mm}$ ) and the lengths from 1.25 to 5 in ( 32 to $127 \mathrm{~mm}$ ). In order to put in this type of screw on hard surfaces such as concrete, the installer usually uses drill hammer in order to create a pilot hole for each item.

\subsubsection{Drywall Screw}

This type of screw is designed with a bugle head and specialized to attach drywall to wood or metal studs. Screws are made of various metals like stainless steel, fibers, iron and copper. Common applications of these screws are in electrical appliances, large machinery and domestic houses. The diameter of drywall screw threads is larger than the shaft diameter.

Table 2: Details of screw that used in this study

\begin{tabular}{|c|c|c|c|c|}
\hline Screw & Length (mm) & Diameter $\mathbf{( m m )}$ & No. of thread & Material \\
\hline Drywall Screw & 50.8 & 2 & 25 & $\begin{array}{c}\text { Low- carbon steel black } \\
\text { phosphate coating }\end{array}$ \\
\hline Chipboard Screw & 50.8 & 4 & 19 & Alloy steel \\
\hline Self-Tapping screw & 50.8 & 4 & 30 & Stainless steel \\
\hline
\end{tabular}

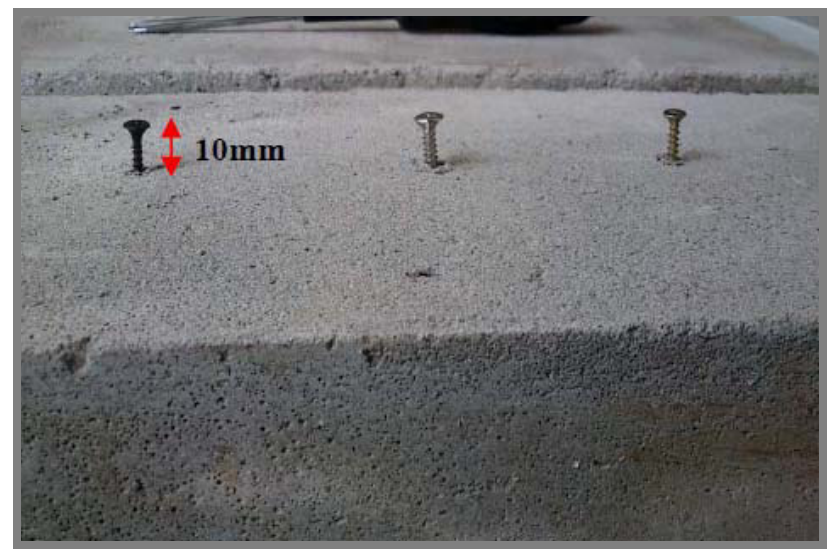

Figure. 3: Installation of screws on sample

\section{Pullout Strength Setup}

A $40.8 \mathrm{~mm}$ length of the screw's shaft will be inserted on sample of foamed concrete with 10 $\mathrm{mm}$ distance from the head of the screw to the surface of sample as shown in Fig. 3. The three types of screw will be installed on a same sample. In order to ensure uniformity of screw placement during the experiment, the screws were induced into foamed concrete by the screwdriver being placed parallel with the long axis of the screw to fit completely on the head of the screw. Repeat the method of inserting screws on the sample with the use of wall plug on it. This machine will measure the ultimate load that can break a screw on foamed concrete. Screw on foamed concrete will be tested using Universal Testing Machine. The hook served as screw holder of the sample. There is a part of Universal Testing Machine that is adjustable. The sample will be placed on this part while the hook will be positioned at the top of the machine that starts from the upper part. When the movable part moves downward, the machine will take the reading of the total load that can make screw fail or 
disengage from the concrete. Since the method of tensile test for rebar was implemented in this study, the hook must be welded on data logger (reader) in order to run the test. Fig. 4 demonstrates how the sample was placed in the testing machine. G clamp was used to hold the sample.

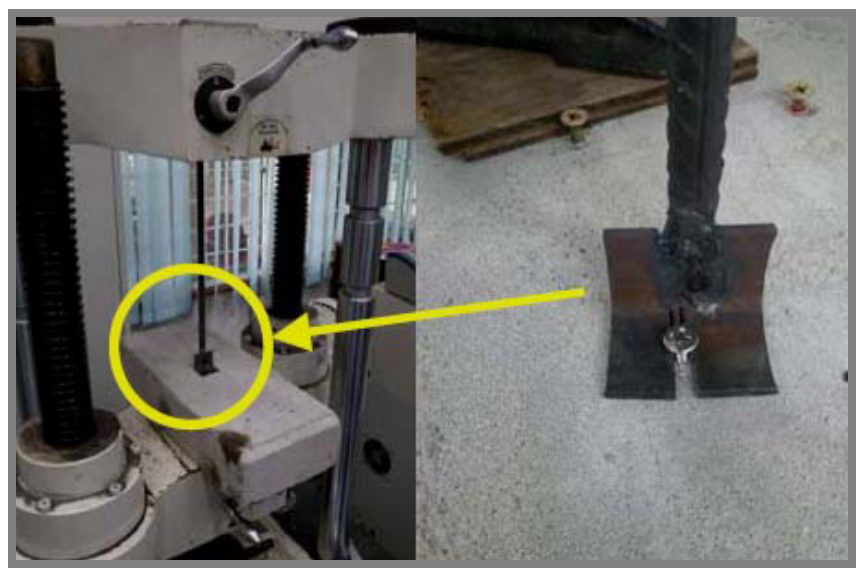

Figure 4: Setting Out of the Sample at Machine

\section{Results and Discussions}

\subsection{Compressive Test}

Compressive test is the primary physical property of concrete and the most important parameter when designing a concrete mix for different purposes. It's also a fundamental property used for quality control for lightweight concrete. Compressive strength can be defined as the ability of concrete specimens to sustain the axial load. In this study foamed concrete cube will be tested after allowing hardening for 7 days and 28 days. Six samples will be utilized for each mixture in order to determine the compressive strength of the concrete. 3 samples will be tested after 7 days the other 3 samples will be tested after 28 days of hardening. The results of this test are shown in Table 3 and Table 4 below.

Table 3: Compressive strength after 7 days hardening

\begin{tabular}{|c|c|c|}
\hline Density $\left(\mathrm{kg} / \mathrm{m}^{3}\right)$ & Compressive strength at 7-days $\left(\mathrm{N} / \mathrm{mm}^{2}\right)$ & $\begin{array}{c}\text { Average compressive strength } \\
\left(\mathrm{N} / \mathrm{mm}^{2}\right)\end{array}$ \\
\hline \multirow{3}{*}{900} & 0.85 & \multirow{2}{*}{0.85} \\
\cline { 2 - 2 } & 0.88 & \\
\cline { 2 - 2 } & 0.82 & \multirow{2}{*}{2.65} \\
\cline { 2 - 2 } & 2.44 & \\
\cline { 2 - 2 } & 2.47 & \\
\hline \multirow{3}{*}{1250} & 3.04 & \\
\hline
\end{tabular}

Table 4: Compressive strength after 28 days hardening

\begin{tabular}{|c|c|c|}
\hline Density $\left(\mathrm{kg} / \mathrm{m}^{3}\right)$ & Compressive strength at 7-days $\left(\mathrm{N} / \mathrm{mm}^{2}\right)$ & $\begin{array}{c}\text { Average compressive strength } \\
\left(\mathrm{N} / \mathrm{mm}^{2}\right)\end{array}$ \\
\hline \multirow{3}{*}{900} & 0.76 & \multirow{2}{*}{0.92} \\
\cline { 2 - 2 } & 0.95 & \\
\cline { 2 - 2 } & 1.05 & \multirow{2}{*}{3.10} \\
\cline { 2 - 2 } & 2.44 & \\
\cline { 2 - 2 } & 2.47 & \\
\hline \multirow{2}{*}{1250} & 3.04 & \\
\end{tabular}


Based on the compressive strength results shown in the Table 3 and Table 4, it can be concluded that the results matched the requirement of compressive strength as per published by previous researchers. The typical compressive strength of the foamed concrete range between 800 to 1200 $\mathrm{kg} / \mathrm{m}^{3}$ after 28 days hardening is from 1 to $8 \mathrm{~N} / \mathrm{mm}^{2}$ [5]. This shows that foamed concrete has an adequate amount of strength which to be used in pullout strength test.

\subsection{Pullout strength of screw}

The pullout strength of the screws will be measured in unit kilogram $(\mathrm{kg})$ as the researchers would like to distinguish the load that could be held by screw on foamed concrete material. Universal Testing Machine will give the maximum load of reading. The results of pullout strength are shown in Table 5 and Table 6.

Table 5: Pullout strength result for foamed concrete density $900 \mathrm{~kg} / \mathrm{m}^{3}$

\begin{tabular}{|c|c|c|c|}
\hline \multirow{2}{*}{ Types of Screw } & Sample & $\begin{array}{c}\text { Unplugged Screw Result } \\
(\mathbf{k g})\end{array}$ & Plugged Screw Result (kg) \\
\hline \multirow{3}{*}{ Chipboard Screw } & 1 & 25.7 & 28.0 \\
\cline { 2 - 4 } & 2 & 26.4 & 42.3 \\
\cline { 2 - 4 } & 3 & - & 33.9 \\
\hline \multirow{3}{*}{ Self-tapping Screw } & 1 & 31.6 & 34.5 \\
\cline { 2 - 4 } & 2 & 28.2 & 32.4 \\
\cline { 2 - 4 } & 3 & - & 29.3 \\
\hline \multirow{3}{*}{ Drywall Screw } & 1 & 25.8 & 25.5 \\
\cline { 2 - 4 } & 2 & 34.5 & 32.2 \\
\cline { 2 - 4 } & 3 & - & 37.3 \\
\hline
\end{tabular}

Minimum reading that could be recorded by Universal Testing Machine is $25 \mathrm{~kg}$. Therefore, the result for some tests cannot be obtained because of low reading. This is due to the testing method that that is designed for tensile stress which usually resulted in higher ultimate load. From Table 5, we can see an inconsistence result of pullout strength of each test. For chipboard, the highest and the lowest reading of pullout strength for plug screw shows a significantly different result.

Table 6: Pullout strength result for foamed concrete density $1250 \mathrm{~kg} / \mathrm{m}^{3}$

\begin{tabular}{|c|c|c|c|}
\hline \multirow{2}{*}{ Types of Screw } & Sample & $\begin{array}{c}\text { Unplugged Screw Result } \\
(\mathbf{k g})\end{array}$ & Plugged Screw Result (kg) \\
\hline \multirow{3}{*}{ Chipboard Screw } & 1 & 140.5 & 144.0 \\
\cline { 2 - 4 } & 2 & 135.8 & 138.4 \\
\cline { 2 - 4 } & 3 & 125.0 & 169.1 \\
\hline \multirow{3}{*}{ Self-tapping Screw } & 1 & 148.5 & 188.9 \\
\cline { 2 - 4 } & 2 & 146.3 & 142.6 \\
\cline { 2 - 4 } & 3 & 155.9 & 217.7 \\
\hline \multirow{3}{*}{ Drywall Screw } & 1 & 107.1 & 108.8 \\
\cline { 2 - 4 } & 2 & 83.1 & 99.9 \\
\cline { 2 - 4 } & 3 & 91.6 & 100.2 \\
\hline
\end{tabular}

Based on the result shown on Table 5 and Table 6, it shows that different densities will create different give different pullout strength. Higher density of concrete will give higher pullout strength of screw. The use of wall plug evidently will resulted better pullout strength. Three different types of screw gave different reading of pullout strength. Based on Table 6, it can be seen that the result was consistence on high density of foamed concrete to differentiate the pullout strength of three different type of screw on foamed concrete. Compared to pullout strength at low density shows different type of screw are not really effected the pullout strength of screws because of the result were not too different to each type of screw. 


\section{Conclusions}

This paper has presented the results of a pilot study to qualify the mechanical performance of pullout strength of screws on foamed concrete. Three different types of screw were used on two different levels of foamed concrete's densities. From the experiments and comparative results the following conclusion may be drawn.

1. The results shows higher density of foamed concrete will give higher pullout strength of screw on foamed concrete.

2. Throughout this study, and based on consistent result at the test on foamed concrete density 1250 $\mathrm{kg} / \mathrm{m}^{3}$, we can see Self-Tapping Screw was give the best pullout strength. This is because it have a large number of thread on it shaft. Chipboard screw in this test have same shaft diameter. Because of that, two other types of screws give higher pullout strength compared to drywall screw that have smaller diameter of shaft.

3. The use of wall plug on foamed concrete will strengthen the stranglehold of screw on the concrete.

\section{Acknowledgement}

The authors would like to thank Universiti Sains Malaysia for their support under USM Short Term Grant (203/PPBGN/6312147)

\section{References}

1. Othuman Mydin, M.A., Y.C. Wang, 2012. Mechanical properties of foamed concrete exposed to high temperatures. Journal of Construction and Building Materials, 26 (1): 638-654

2. Awang, H., M.A. Othuman Mydin, A.F. Roslan, 2012. Microstructural investigation of lightweight foamed concrete incorporating various additives. International Journal of Academic Research, 4 (2): 197-201

3. Othuman Mydin, M.A., 2013. Modeling of Transient Heat Transfer in Foamed Concrete Slab. Journal of Engineering Science and Technology, 8 (3): 331-349

4. Herki, B.A., J.M. Khatib, E.M. Negim, 2013. Lightweight Concrete Made from Waste Polystyrene and Fly Ash. World Applied Sciences Journal, 21 (9): 1356-1360

5. Othuman Mydin, M.A., Y.C. Wang, 2012. Thermal and mechanical properties of Lightweight Foamed Concrete (LFC) at elevated temperatures. Magazine of Concrete Research, 64 (3): 213 224

6. Soleimanzadeh, S., M.A. Othuman Mydin, 2013. Influence of High Temperatures on Flexural Strength of Foamed Concrete Containing Fly Ash and Polypropylene Fiber, International Journal of Engineering, 26 (1): 365-374

7. Roslan, A.H., H. Awang, M.A. Othuman Mydin, 2013. Effects of Various Additives on Drying Shrinkage, Compressive and Flexural Strength of Lightweight Foamed Concrete (LFC). Advanced Materials Research Journal, 626: 594-604

8. Othuman Mydin, M.A., 2011. Thin-walled steel enclosed lightweight foamed concrete: A novel approach to fabricate sandwich composite. Australian Journal of Basic and Applied Sciences, 5 (12): 1727-1733

9. Norgaard, J., M.A. Othuman Mydin, 2013. Drywall Thermal Properties Exposed to High Temperatures and Fire Condition. Jurnal Teknologi, 62 (1): 63-68

10. Othuman Mydin, M.A., 2013. An Experimental Investigation on Thermal Conductivity of Lightweight Foamed concrete for Thermal Insulation. Jurnal Teknologi, 63 (1): 43-49 
11. Awang, H., M.A. Othuman Mydin, A.F. Roslan, 2012. Effects of Fibre on Drying Shrinkage, Compressive and Flexural Strength of Lightweight Foamed Concrete. Advanced Materials Research, Trans Tech Publications, Switzerland, 587: 144-149

12. Othuman Mydin, M.A., Y.C. Wang, 2011. Structural Performance of Lightweight Steel-Foamed Concrete-Steel Composite Walling System under Compression. Journal of Thin-walled Structures, 49 (1): 66-76

13. Othuman Mydin, M.A., Y.C. Wang, 2011. Elevated-Temperature Thermal Properties of Lightweight Foamed Concrete. Journal of Construction \& Building Materials, 25 (2): 705-716

14. Babalola, M.R., R.A. LaBoube, 2004. Strength of Screw Connections Subject to Shear Force, American Iron and Steel Institute, Research Report RP04-2, pp: 1-29.

15. Abshire, B.B., R.F. McLain, A. Valdevit, H.E. Kambic, 2001. Characteristics of pullout failure in conical and cylindrical pedicle screws after full insertion and back-out. The Spine Journal, 1: 408-414

16. Flahiff, C.M., G.A. Gober, R.W. Nicholas, 1995. Pullout strength of fixation screws from polymethylmethacrylate bone cement. Biomaterials, 16: 533-536.

17. Fomina, E.V., V.V. Strokova, 2013. Application of Natural Aluminosilicates in Autoclave Cellular Concrete. World Applied Sciences Journal, 25 (1): 48-54 